Asst. Prof. Dr. Bahadır KÖKSALAN ${ }^{1}$

Asst. Prof. Dr. Hikmet ZELYURT ${ }^{2}$

Original scientific paper

İnönü University, The Faculty of Education

UDC: 37.014

The Department of Primary Education

The Department of Pre-school Teaching

Malatya, Turkey

\title{
DEVELOPMENT OF THE “PERCEIVED TEACHER BEHAVIOURS” SCALE IN PRIMARY SCHOOL
}

\begin{abstract}
The study is aimed at developing a valid and reliable measurement instrument intended to identify the perception of the third and fourth grade primary school pupils in relation to their teachers' behaviour throughout their education. The analysis of the related literature and the draft version of the scale were prepared after obtaining expert opinion and trials conducted in the second term of 2015-2016 school year in different state primary schools under the jurisdiction of the provincial directorate of national education in Malatya on the sample of the third and fourth grade pupils. Expert opinion was obtained to determine the content and face validity of the scale and for construct validity. Exploratory Factor Analysis (EFA) and Confirmatory Factor Analysis (CFA) were also conducted. For statistical operations, studies on 25 items were carried out. Findings obtained based on EFA and CFA analyses suggested that fit indices of the structure of the scale of perceived teacher behaviour were sufficient. The Pearson Correlation Coefficient between the obtained scale and the scores of the testretest method was also found to be at reasonable level. Based on these findings, it was concluded that the scale of perceived teacher behaviour is an instrument that produces valid and reliable measurements and it could be used to measure the pupils' perception of teacher behaviour.
\end{abstract}

Key Words: teacher, perceived behaviour, scale development, primary school.

\section{INTRODUCTION}

While studying, pupils find themselves in a community system moulded by the school, family and environment consisting of the teacher, teaching environment and education-training program. Each element of the system has a different importance. The only constant factor among the changing elements of this system is pupil's success and the studies that increase this success. The attitudes and behaviours towards the child and significance of coordination among pupil - parent - teacher are emphasized by scholars on all occasions due to the fact that teacher's and parent's perceptions of the child have an important effect on his/her learning. The studies carried out on children and the problems they are facing with suggest

\footnotetext{
${ }^{1}$ bahadir.koksalan@inonu.edu.tr

22hikmet.zelyurt@inonu.edu.tr
} 
that the school-family-child triangle is inevitably a responsibility relation. "It is an accepted fact that the individual's attitudes and behaviours are affected by his family and school". At the same time, it can be seen that the child's behaviour and attitudes also affect his family (Acar, 2000). The basic approach of the family and the teacher towards learning is that the child reaches success by studying. Learning a lesson is naturally required to be successful (Uluğ, 1991). According to this view, studying and being successful have the same importance (Kara, 2008). The way children perceive their teacher and family is also considered important. Making the teaching-learning activities easier and increasing the pupils' learning performances require knowledge about pupils' feelings, motivation, and what they should do and how they should act to reach their goals.

Elements of the school system, such as the way pupils communicate with their teacher, technological equipment in the school and family environment, education program, and appropriateness of the teaching environment affect the learning process in different ways. The way pupils perceive their teachers in the teaching process is also one of the elements that is believed to affect this process. The level of child's perception of the teacher can be examined on the basis of the level of education, age or other variables. This study is aimed at developing a reliable and valid measurement instrument that measures the perception of the third and fourth grade primary school pupils about how their teachers behave towards them during the educational process.

The study started by creating a draft scale based on expert opinion and tests, and analysing the corresponding literature. The study was conducted in the second term of the 2015-2016 school year on the sample of the third and fourth grade primary school pupils in Rahmi Akıncı, Kazım Karabekir, Kemal Özalper, Derme, Cengiz Topel, Barbaros, Melekbaba and Gazibelonging to the Battalgazi district of Malatya provincial education directorate. Expert opinions were obtained for the content and face validity of the scale and for construct validity, and Exploratory Factor Analysis (EFA) and Confirmatory Factor Analysis (CFA) were conducted. For statistical operations, 25 items were taken in consideration. The results obtained based on the CFA for the second study group were found to have adequate fit indices of structure relating to perceived teacher behaviours. The Pearson Correlation Coefficient between the obtained scale and the scores of test-retest method was also determined. These findings indicated that the scale is a valid and reliable measurement instrument and it could be used to measure how the primary school pupils perceive their teachers' behaviour.

\section{METHOD}

\section{Design - Model}

The study has been designed as a screening model, which is one of the quantitative research methods. It serves as a model of instant screening. This research model is defined in the same way as the models in the studies that describe available situations in certain time (Büyüköztürk, vd. 2018, pg.185). The study was intended to develop a reliable and valid measurement instrument to determine teacher's behaviour perceived by primary school pupils, which is one of the variables of the learning/teaching environment. The research was carried out in accordance with this purpose and was performed as a study of scale development. 


\section{First Study Group}

The study was based on a descriptive method, i.e.a screening model. The sample of the respondents consisted of pupils attending primary schools located in Battalgazi district of Malatya in the second term of the 2015-2016 school year. Pupils in the sample of the study were selected in a way to represent the population. After the first analysis conducted upon the application of the related scale and after eliminating the forms that were filled wrongly or incompletely, data relating to a total of 1130 pupils were analysed. The first study group consisted of 619 (54.8\%) boys and 511 (45.2\%) girls, of which $38.7 \%$ (437) were attending the third grade and $61.4 \%$ (693) the fourth grade.

\section{Second Study Group}

After analysing the first group, a second study group was required for confirmatory factor analysis to get healthier results after exploratory factor analysis (Henson and Roberts, 2006). The new study group was formed by taking into account that the characteristics of the second group should be similar to those of the first group. Accordingly, the scale was applied to pupils attending the first term of the 2016-2017 school year in primary schools located in Battalgazi district of Malatya. After the first analysis conducted upon the application of the related scale and after eliminating the forms that were filled wrongly or incompletely, data relating to a total of 210 pupils were analysed. The first study group consisted of 116 (55.2\%) boys and 94 (44.8\%) girls, of which 50\% (105) were attending the third grade and 50\% (105) the fourth grade.

\section{Development of the data-collecting tool}

The choice of method in studies is also defined as collecting the data relevant to the research and determining the details related to their analysis (Ural, Kılıç: 2006, 53). The most appropriate methods and techniques were used by taking the aim, process and approach of the research into account while choosing the applications and activities. In this study, the development of the "perceived teacher behaviours" scale in primary school was realized by taking the following steps: preparation of scale items, content validity, pre-test study, determining construction validity and reliability (Karasar, 1995: 139-143).

\section{Pool of Items}

Taking account of the basis and procedures of item preparation in the study, items were primarily chosen based on the size and the scope of the study. Elements (statements) in coordination with the objective were created in line with sub-goals. Questions for the pool of items were compiled by making use of the study called "Personality Traits of Teachers". On the other hand, the study "Classroom Management Models" was also analysed, completing thereby the review of relevant literature. Previous scales prepared on this subject were also analysed (Saydam and Telli, 2011; Karadağ, Baloğlu and Yalçınkayalar, 2006; Nartgün, 2008; Çağlar, Yakut and Karadağ, 2005; Kılınç, 2014; Kurt, 2013; Erdoğdu, 2013; Albayrak, Güngören and Horzum, 2014; Atik and Üstüner, 2014; Özer, Gençtanırım and Ergene, 2011; Baykara Pehlivan, 2005). The researchers asked four different classes, each consisting of 30 pupils, to answer the question "How would you like your teachers to behave towards you?" and asked them to rank these answers. After classifying the answers, 83 draft items were created. In the later stage, Master and Doctorate students were asked to analyse these statements and the 
results were sent to instructors and their assistants, who were asked to review them and make appendices and deductions to these items. Thus, based on expert opinion, the authors sought to provide the content validity of items. Items included in the pool were preliminarily evaluated based on the instructors' views. As a result, 57 items were included in the pool. The scale was designed as a 3-point Likert scale with the following scores: agree: 3 pts., hesitant: 2 pts., disagree: 1 pt.

\section{Expert Opinion (Content Validity)}

Six lecturers, including two education programme experts, two educational psychology experts and two educational administration experts were asked for their opinions regarding the items in the pool of items. In addition, support was received from an expert lecturer in the field of Turkish Language Teaching in order to ensure the prepared items' clarity and grammar correctness.

\section{Procedure}

In accordance with several expert opinions, the draft scale was applied to almost 120 pupils from the first through fourth grades as a pilot scheme, and they were asked to identify the items which they find difficult to understand. All the items marked were rearranged according to expert's opinions and support. At the end of this study, "The Development of Perceived Teacher Behaviours Scale" was made ready for pre-application, as it would include $57 \mathrm{draft}$ items. After having expert opinions and pre-tests, the data were collected by applying the scale to 1130 third and fourth grade pupils from different primary schools in Battalgazi district of the Malatya province.

\section{Factor Analysis}

After the application of the draft scale to 1130 pupils, factor analysis was carried out. The sample group consisted of $54.8 \%$ (619) boys and $45.2 \%$ girls. Based on the results of the analysis, the items which construct validity was proven were included in the final version of the scale. The factor analysis was focused on the fact that Kaiser-Meyer-Olkins (KMO) values were high.

\section{Calculating theScale of Reliability}

After factor analysis, when the scale was in its final form, the Cronbach alpha coefficient of internal consistency was calculated. In order to avoid any mistake in the coefficient of reliability, all operations were repeated twice in a controlled way under the supervision of the authors, and these operations that were conducted separately yielded with the same results (Bayram, 2004: 128). It was stated that it is enough for Cronbach Alpha value to be higher than.70 in terms of reliability. In order to determine the variables that did not equally share the common value that was measured and to increase the internal consistency of the scale by excluding these variables from the analysis, the variables were first applied on the basis of factor and then they were subjected to a reliability test (Baş, 2005: 193). In the stage of analysis, Cronbach Alpha and Part-Whole Correlation were used to identify statements that did not reflect the common value which was to be measured. The operations were conducted using the SPPS 21.0 program package, and were repeated until all the statements negatively affecting the reliability of each factor were excluded. Then, in the second stage, all factors 
were examined by this test again. At the end of this analysis, 33 out of 57 items were excluded from the scale.

\section{FINDINGS AND COMMENTS}

\section{Explanatory Factor Analysis}

The scale developed to determine how the primary school pupils perceive their teachers' behaviours, attitudes and manners was called "Perceived Teacher Behaviours Scale". The draft scale was taken in factor analysis with 25 items and at the end of the analysis 9 statements were discarded. Thus, the scale included a total of 16 statements.

\begin{tabular}{ll}
\hline \multicolumn{1}{c}{ Table 1- Item loading values } & Item loading values \\
\hline My teacher always shouts. & .486 \\
My teacher always says. “Stop speaking.” & .684 \\
I do not like my teacher. & .385 \\
My teacher scolds me. & .583 \\
My teacher fails to check my homework. & .443 \\
My teacher does not like me. & .353 \\
I cannot ask my teacher questions because I am afraid. & .529 \\
I refrain from my teacher's reaction. & .355 \\
My teacher knows me very well. & .527 \\
My teacher blames me on everything. & .445 \\
My teacher does not care for me. & .464 \\
My teacher does not give me tasks. & .349 \\
We study even if my teacher is not in the class. & .351 \\
My teacher goes over subject-mattereven if I do not & .572 \\
understand it. & .425 \\
My teacher behaves angrily. & .447 \\
My teacher fails to help me with the lessons. &
\end{tabular}

The factor loading in the final version of the scale varies between .349 and .684 (Table 1). After the factor analysis, it can be concluded that the "Perceived Teacher Behaviours Scale" consisting of 16 items was a valid scale (Nunally and Bernstein, 1994). As a result of the onedimensional scale, three sub-dimensions appeared. Coefficients of internal consistency of these sub-dimensions were determined using the Cronbach Alpha values (Table 2). Based on these values, it was concluded that the scale is reliable.

Table 2- Reliability and Validity of Attitude Scale

\begin{tabular}{lllll}
\hline & Negative & Caring & Repressive & Total \\
\hline Cronbach Alpha & .799 & 56.1 & .538 & .777 \\
KMO & .862 & .606 & .583 & .867 \\
Bartlett Test of Sphericity & 2478.713 & 341.489 & 140.896 & 3745.486 \\
Number of valid items & 10 & 3 & 3 & 16 \\
\hline
\end{tabular}

KMO values, Bartlett test and Cronbach Alpha coefficients of internal consistency of the scale were calculated in relation to various sub-dimensions of the scale. Statements in the sub- 
dimensions identified after factor analysis were examined and the sub-dimensions were given names with the support of different lecturers and master students. Attention was paid to the fact that KMO values of both the sub-dimensions and the whole scale were higher than .50 and Bartlett test was significant $(p<0.05)$ (Büyüköztürk, 2004:120). The authors made sure that the value of factor loading after the analysis was higher than .349 (Nunally and Berstein, 1994). After the repeated factor analysis, values of the KMO, Bartlett test of Sphericity and Cronbach Alpha of the scale with three sub-dimensions were .867, 3745.486 and .777, respectively. Loading values of each attitude statement in the scale after the factor analysis are given in Table 3.

Table 3-Rotated Components Matrix after Factor Analysis

\begin{tabular}{|c|c|c|c|}
\hline & Negative & Caring & Repressive \\
\hline My teacher blames me on everything. & .639 & & \\
\hline My teacher does not care for me. & .634 & & \\
\hline My teacher scolds me. & .617 & & \\
\hline I cannot ask my teacher questions because I am afraid. & .614 & & \\
\hline My teacher does not give me tasks. & .574 & & \\
\hline My teacher behaves angrily. & .548 & & \\
\hline My teacher fails to help me with my lessons. & .535 & & \\
\hline I refrain from the teacher's reaction. & .532 & & \\
\hline My teacher fails to check my homework. & .524 & & \\
\hline My teacher does not like me. & .497 & & \\
\hline My teacher knows me very well. & & .749 & \\
\hline We study even if my teacher is not in the class. & & .690 & \\
\hline My teacher goes over subject-matter even if I do not understand it. & & .575 & \\
\hline My teacher always shouts. & & & .825 \\
\hline My teacher always says. "Stop speaking." & & & .596 \\
\hline I do not like my teacher. & & & .411 \\
\hline
\end{tabular}

One of the operations conducted using the SPSS 21.00 is to determine the extent to which items in the final version of the three-dimensional scale define the subject. For that purpose, results obtained from the Total Variance Explained test are given in Table 4 below.

Table 4- Total Explanatory Variance Values of Sub-dimensions

\begin{tabular}{|c|c|c|c|c|}
\hline Sub-dimensions & Eigenvalue & of Sub-dimensions & Total Explanatory & Variance (\%) \\
\hline Negative & & 4.133 & 22.225 & \\
\hline Caring & & 2.116 & 35.826 & \\
\hline Repressive & & 1.048 & 45.608 & \\
\hline
\end{tabular}

As seen in Table 4, the rate of determination of the three dimensions forming the "Perceived Teacher Behaviours Scale" was found to be higher than $50 \%$ in total percentage. This rate is reasonable in social sciences (Nunally and Bernstein, 1994). 


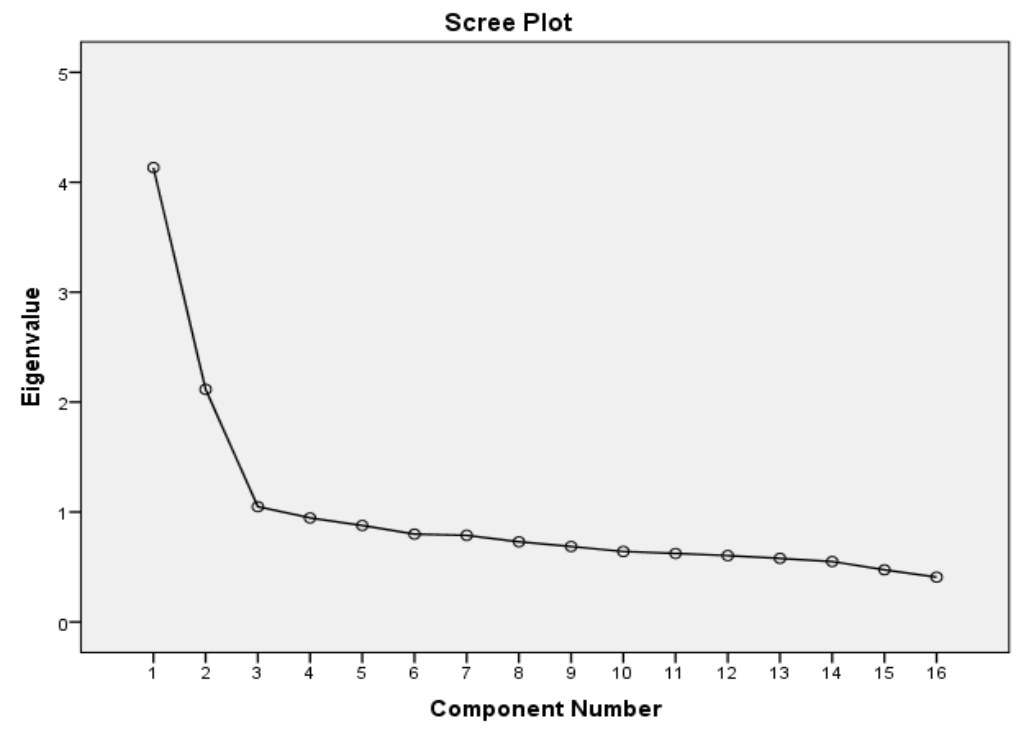

\section{Confirmatory Factor Analysis}

The Lisrel 8.71 program package was used to conduct confirmatory factor analysis in order to confirm the explanatory factor analysis. The data from the second study group were evaluated based on confirmatory factor analysis to confirm the 3 -factor model, which includes 16 items obtained from the explanatory factor analysis. It can be seen that the values of $t$ were significant at the level of 0.01 concerning the definition of observed variables by latent variables for the three-factor model (Çokluk, Şekercioğlu and Büyüköztürk, 2010; Seçer, 2015). It can also be seen from the model that the defined standardised parameter values of latent variables in relation to observed variables are between 0.08 and 0.57 , while the error variances of observed variables are between 0.16 and 0.72 . According to the literature, these values are on a reasonable level (Çokluk, Şekercioğlu and Büyüköztürk, 2010; Şimşek, 2007; Seçer, 2015). Below are given the values of goodness of fit for the model that were obtained before and after the modifications were introduced. Values relating to goodness of fit were determined as "perfect, reasonable or poor" according to the criteria generally accepted in the literature (Çokluk, Şekercioğlu and Büyüköztürk, 2010; Seçer, 2015; Brown, 2006; Şimşek, 2007; Tabachnick and Fidell, 2007).

In the confirmatory factor analysis, a significant difference between the expected and observed covariance matrix has been found for the three-factor model $(p<0.05)$. The value of $p$ is required not to be significant, but this is probably because of the size of the sample group. Therefore, alternative fit indices were examined. While parameters of $X^{2} / s d, R M S E A, R M R, C F I$ and NNFI were on a reasonable level in the first analysis, other values were poor. In this stage of confirmatory factor analysis, suggestions for modification should be considered in order to improve the model. According to the results obtained using the Lisrel program, it is stated that the relation between error variances of items "The teacher fails to notice me." and "The teacher scolds me." should be defined. 
Table 5 - Results of Confirmatory Factor Analysis of the Scale

\begin{tabular}{lllll}
\hline Goodness of fit values & $\begin{array}{l}\text { Perfect } \\
(\mathrm{M})\end{array}$ & $\begin{array}{l}\text { Reasonable } \\
(\mathrm{K})\end{array}$ & Before modification & $\begin{array}{l}\text { After modification } \\
(\mathrm{V} 15-\mathrm{V} 14)\end{array}$ \\
\hline $\mathrm{P}$ & $>0.05$ & $<0.05$ & $0.01(\mathrm{~K})$ & $0.01(\mathrm{~K})$ \\
$\mathrm{X}^{2} / \mathrm{sd}$ & $<3$ & $3-5$ & $143.13 / 101=1.41(\mathrm{M})$ & $134.61 / 100=1.34(\mathrm{M})$ \\
$\mathrm{RMSEA}$ & $<0.05$ & $<0.08$ & $0.045(\mathrm{M})$ & $0.041(\mathrm{M})$ \\
$\mathrm{RMR}$ & $<0.05$ & $<0.08$ & $0.036(\mathrm{M})$ & $0.035(\mathrm{M})$ \\
SRMR & $<0.05$ & $<0.08$ & $0.058(\mathrm{~K})$ & $0.057(\mathrm{~K})$ \\
GFI & $>0.95$ & $>0.90$ & $0.92(\mathrm{~K})$ & $0.93(\mathrm{~K})$ \\
AGFI & $>0.95$ & $>0.90$ & 0.89 & $0.90(\mathrm{~K})$ \\
CFI & $>0.95$ & $>0.90$ & $0.96(\mathrm{M})$ & $0.97(\mathrm{M})$ \\
NFI & $>0.95$ & $>0.90$ & 0.89 & $0.90(\mathrm{~K})$ \\
NNFI & $>0.95$ & $>0.90$ & $0.95(\mathrm{M})$ & $0.96(\mathrm{M})$ \\
\hline
\end{tabular}

After introducing the suggested modification, the value of chi-square $\left(X^{2}\right)$, which is one of the fit indices, significantly decreased. The chi-square that cannot be evaluated alone has reached a perfect level when comparing with the degree of freedom $\left(X^{2} / s d=1.34\right)$. In addition, it can be seen that the difference between the expected and the observed matrix of covariance obtained for the model was on a reasonable level $(p<0.05)$. In addition, the obtained fit index is at the level of 0.041 in the Root Mean Square Error of Approximation (RMSEA). If the RMSEA value is equal to or lower than .05 , the fit is perfect, if it is .08 or below, the fit is reasonable, and if it is .10 and higher, the fit is poor. Thus, it can be concluded that the fit index obtained for the analysis is perfect. The Standardized Root Mean Square Residuals (SRMR) index is .057. The fact that the RMR and standardized RMR are lower than .05 indicate a perfect fit; values lower than .08 indicate a good fit, and values below .10 a reasonable fit. Accordingly, it can be stated that, for the analysis performed, the standardized RMR has a reasonable fit, while the RMR has a perfect fit.

In fit indices, it can be seen that Goodness of Fit Index (GFI) is .93 and Adjusted Goodness of Fit Index (AGFI) is .90. Values of GFI and AGFI range between 0 and 1. GFI and AGFI values of .95 and higher indicate a perfect fit, while values between .90 and .94 indicate a reasonable fit (Schumacker and Lomax 2004; Hooper, Caughlan and Mullen, 2008). Accordingly, it was concluded that GFI and AGFI values present a reasonable fit index.

Considering the non-normed fit index (NNFI), the normed fit index (NFI) and the comparative fit index (CFI), their values are $.96, .90$ and .97 , respectively. With NNFI, NFI and CFI values higher than .95, the fit is perfect, while with values higher than .90, the fit is reasonable (Sümer, 2000). Accordingly, it can be concluded that NNFI and CFI have a perfect fit, while the $\mathrm{NFI}$ has a reasonable fit for the analysis performed.

The path diagram including standardized factor loadings, error variances and modifications at the end of confirmatory factor analysis is shown in Figure 2. 


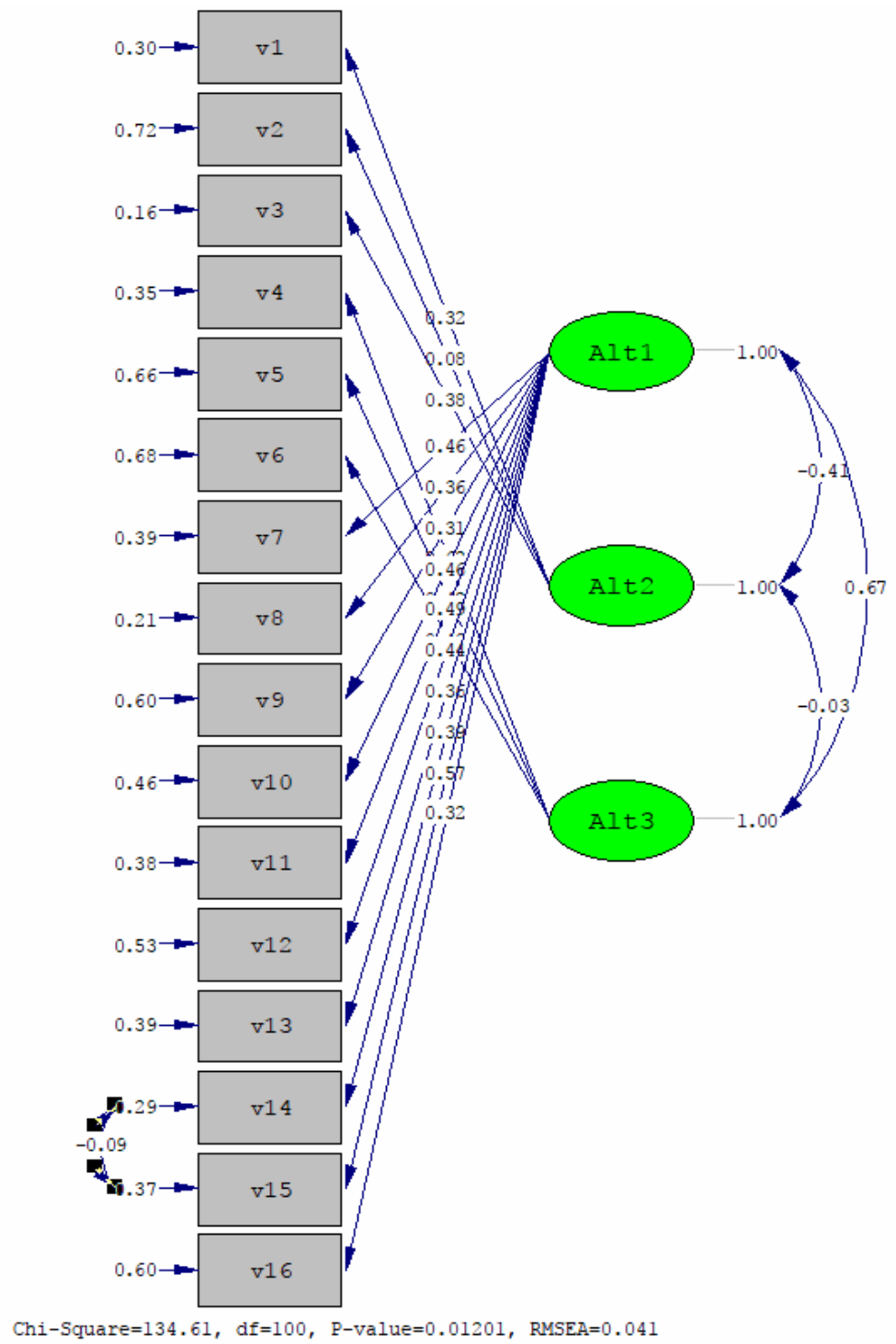

Figure 2- Path diagram of the four-dimensional model after modification

\section{Reliability of the Scale in Time}

As a result of the exploratory and confirmatory factor analysis, the test-retest correlation coefficient relating to the score invariance of the scale, the final version of which is given in Appendix-1, was tested on a group consisting of 220 pupils for reliability calculations in time. The scale was reapplied to the same individuals within the interval of three weeks. The Pearson Correlation Coefficient between these two applications was found to be $r=0.84$. Based on this result, it was accepted that measurements conducted using the scale were reliable (Ekici, 2009). 


\section{RESULTS}

Based on the findings of this study, it was concluded that the Perceived Teacher Behaviours Scale was confirmed to be a three-factor model with 16 items, and the developed scale that presents the way primary school pupils perceive their teacher's behaviours is composed of three sub-dimensions; negative, caring and repressive teacher. The developed model was subjected to exploratory factor analysis and confirmatory factor analysis, respectively. Based on the conducted factor analysis, item pool, expert opinion, and workout during the process of Exploratory Factor Analysis, it was concluded that the values of Cronbach's Alpha coefficient of reliability, KMO and Bartlett Test of Sphericity for each dimension and the values of the total exploratory variance of the scale's sub-dimensions were at reasonable level. Then, the fit indices of the developed model resulting from confirmatory factor analysis suggested that the model was not discarded, and the reliability of the model was confirmed. In addition, it was determined that all standardized parameter values are reasonable or perfect, and thus the validity of all formations is convergent (Chou, Boldy and Lee, 2002, 52). Results obtained in the context of the study suggest that the scale is a valid and reliable measurement instrument.

\section{REFERENCES}

Acar, N.V. (2000). Ergenvecocuklailetisim. US-A yayincilik. Ankara.

Albayrak, E., Gungoren, O.C. ve Horzum, M.B. (2014). Algilanan ogrenme olceginin Turkceye uyarlamasi. Ondokuzmayısuniversitesiegitimfakultesidergisi, 33(1), 1-14.

Atik, S. ve Ustuner, M. (2014). Ilkogretim okullarinin orgut tipi ile ogretmenlerin orgutsel bagliligi arasindaki iliski. Ahi EvranuniversitesiKirsehiregitimfakultesidergisi, 15(2), 133154 .

Bas, T. (2005). Anketnasilhazirlanir, uygulanir, degerlendirilir?3. basim, Ankara: SeckinYayincilik. Bayram, N. (2004). Sosyalbilimlerde SPSS ileveriAnalizi. Bursa: EzgiKitabevi.

Baykara Pehlivan, K. (2005). Ogretmenadaylarininiletisimbecerisialgilariuzerinebirarastirma. Ilkogretim-Online, 4(2), 17-23.

Brown, T. A. (2006). Confirmatory factor analysis for applied research. New York \& London: The Guilford Press.

Buyukozturk, S. (2004). Sosyal bilimler icin veri analizi el kitabı. 4. basim, Ankara: Pegem A Yayincilik.

Buyukozturk, S., Kilic Cakmak, E., Akgun, O. E., Karadeniz, S., Demirel, F. (2018) Bilimsel Arastirma Yontemleri. 24.basim, Ankara: Pegem A Yayincilik.

Chou, S.C., Boldy, D.P. ve Lee, A.H. (2002). Measuring job satisfaction in residential aged care, International journal for health care, 14(1), 49-54.

Caglar, A., Yakut, O. VeKaradag, E. (2005).

Ilkogretimokulumudurlerininogretmenlertarafindanalgilanankisilikozellikleriveliderlik davranislariarasindakiiliskinindegerlendirilmesi. Egeegitimdergisi, 6(1), 61-80.

Cokluk, O., Sekercioglu, G. VeBuyukozturk, S. (2010). Sosyalbilimlericincokdegiskenliistatistikspssvelisreluygulamalari. Pegemakademiyayinlari, Ankara.

Ekici, G. (2009). Biyolojioz-yeterlikolcegininTurkceyeuyarlanmasi, Kastamonuegitimdergisi, 17(1),111-124.

Erdogdu, M.Y. (2013). Algilananogretmendavranislariolceginingelistirilmesi. Inonuuniversitesiegitimfakultesidergisi, 14(1), 115-128. 
Henson, R.K. \& Roberts, J.K. (2006). Use of exploratory factor analysis in published research: common errors and some comment on improved practice,Educational and psychological measurement, 66, 393-416.

Hooper, D., Caughlan, J. \& Mullen, M.R. (2008). Structural equation modeling: guidelines for determining model fit. Electronic journal of business research methods, 6(1), 53-60. http://arrow.dit.ie/cgi/view content.cgi?article=1001\&context=buschmanart (ErisimTarihi: 08.11.2015).

Kara, A. (2008). IlkogretimBirinciKademede EgitimdeMotivasyon Olceginin Turkceye Uyarlanmasi. Ege EgitimDergisi, 9(2), 59-78.

Karadag, E., Baloglu, N. VeValcinkayalar, P. (2006).

Ilkogretimokuluyoneticilerininogretmenlertarafindanalgilanandemokratiktutumlariil eogretmenlerindemokratikdegerleriuzerineiliskiselbirarastirma,Degerleregitimidergisi , 4(12), 65-82.

Karasar, N. (1995). Bilimselarastırmayontemi, kavramlar, ilkeler, teknikler. Besincibasim Ankara: 3 a arastirmaegitimdanosmanlik Itd.

Kilinc, A. C. (2014). Ogretmenprofesyonelizmininbiryordayicisiolarakkulturu. Egitimvebilim, 39(174), 105-118.

Kurt, H. (2013).

Biyolojiogretmenlerininogrencibasarisindansorumlulukalgilarininsinifyonetimiprofille rinegoreanalizi,Turkish studies, 8(6), 473-490.

Nartgun, Z. (2008). Ogretmenadaylariicinolcmevedegerlendirmegenelyeterlikalgisiolcegi: gecerlikveguvenirlikcalismasi. Abantizzetbaysaluniversitesiegitimfakultesidergisi, 8(2), 85-94.

Nunally, J. C., \& Bernstein, I. H. (1994). Psychometric theory. McGraw - Hill publication. III. Edition.

Ozer, A., Genctanirim, D. veErgene, T. (2011). Turkliseogrencilerindeokulterkininyordanmasi: araciveetkilesimdegiskenleriilebir model testi,Educational science, 36(161), 302-317.

Saydam, G. veTelli, S. (2011). Egitimdebirarastirmaalaniolaraksiniftaogrenci ogretmenkisilerarasiiletisimiveogretmenetkilesimolcegi

Bogaziciuniversitesiegitimdergisi, 28 (2).

Secer, I. (2015). Spssvelisrelilepratikverianalizi. 2. baski, aniyayincilik, Ankara.

Sumer, N., (2000). Yapisalesitlikmodelleri: temelkavramlarveornekuygulama.

Turkpsikolojiyazilari, 3 (6), 49-73.

Simsek, O. F. (2007).Yapisalesitlikmodellemesinegiris: temelilkelerveLisreluygulamalari. Ankara: ekinoksyayincilik.

Tabachnick, B.G. \& Fidell, L.S.(2007). Using multivariate statistics. Boston: Pearson education.

Ulug, F. (1991). Okuldabasari.Istanbul: Remzikitabevi.

Ural, A. VeKilic, I. (2006). BilimselArastirmaSurecive SPSS ileverianalizi. Detayyayincilik. Ankara.

\section{Appendix 1- The Scale of Perceived Teacher Behaviours}

Explanation: The following statements determine the perceived teacher behaviour. Please mark the corresponding column with an " $X$ ", indicating the extent to which you agree with the given statement. This study is conducted exclusively with scientific objective. We thank you for your truthful and definitive answers. 


\begin{tabular}{|l|l|l|l|}
\hline & Agree & Hesitant & Disagree \\
\hline 1- My teacher knows me very well. & & & \\
\hline 2-We study even if our teacher is not in the classroom. & & & \\
\hline 3-My teacher goes over subject-mattereven if I do not understand it. & & & \\
\hline 4-My teacher is always shouting. & & & \\
\hline 5-My teacher always says, "Stop speaking." & & & \\
\hline $6-$ I do not like my teacher. & & & \\
\hline 7-My teacher does not like me. & & & \\
\hline 8- My teacher blames me on everything. & & & \\
\hline 9-I refrain from my teacher's reaction. & & & \\
\hline $10-$ My teacher fails to help me with the lessons. & & & \\
\hline $11-$ My teacher behaves angrily. & & & \\
\hline $12-$ My teacher does not give me tasks. & & & \\
\hline $13-$ I cannot ask questions to my teacher because I am afraid. & & & \\
\hline $14-$ My teacher scolds me. & & & \\
\hline $15-$ My teacher does not care for me. & & & \\
\hline $16-$ My teacher fails to check my homework. & & & \\
\hline
\end{tabular}

Bahadır KÖKSALAN was born in 1968 in Kadirli / Osmaniye. He completed primary, secondary and high school education in Kadirli; University graduated from Inönü University, Faculty of Education between 1987-1991. He completed master's degree between 1991-1993 and doctorate between 1993-1999. He has been working as an Assistant Professor since 2000.

Hikmet ZELYURT was born in 1959 in Dogansehir / Malatya. I completed my primary, secondary and high school education in Malatya. I graduated from Inönü University, Faculty of Education in 1988. I completed my master in1994 at and my doctorate in 2011. I have been working as Assistant Professor at İönü University since 2011. 